\title{
The Elves Conceal My Buffalo and My Son \\ Phtdowl Concentration Camp, June 1977
}

\author{
for Ken McCullough
}

I.

I work from 3 A.M. to 10

before I rest my buffaloes

so that they might browse while I go

fetch water for my wife and son.

I keep busy at this and that, not thinking about my buffaloesI'm obsessed, night and day, looking for peace to quell these agonies.

At 3 P.M., I look for my buffaloes to hitch them up and fertilize five hectares of paddy fields, leaving time to play with my son.

But I can't find Mi Khowl'-I search every thicket, but she's nowhere. I ask $A$ Mahp "Where is Mi Khowl?" with a catch of fear in my voice.

Then I vault onto his back and slap him to a gallop with my feet. We search high and low-not a trace. Then I hop down to find my son.

The she-buffalo has vanished. So has my son. Now my life is over. I shout through the forest:

"Oeuy, son! Oeuy, son! Where have you gone? 
To the north, I cry for my son;

I cry all through the mute jungle.

Wading through dismal swamps, I cry

at the top of my lungs for him;

"O, son whom I love, where are you?

$\mathrm{O}$, devas, spirits of the trees,

find my son before the sun sets.

Grandpa Kosei! Father Naga!

Princess Kramum! Pido Mean Roeuddhi!

Borei Indranimitta! Phnong

spirits of this dell! Krabum Chhouk

and Krabum Chheh, my elder spirits,

Please guide me to my son, please save

me from my own execution!

O, Grandpa Suos, I implore you!

lead me from a violent death!"

I quit and return to my shack.

My son is playing by the door.

"Has Proloeung ${ }^{3}$ seen Mi Kwohl?"

"I've been here with them ${ }^{4}$ the whole time."

II.

The sun sinks; the night takes over.

Old People ${ }^{5}$ shout to each other:

"Ta's beast ate an acre of shoots!"

-just the evidence they need. ${ }^{6}$

III.

At 9 the next morning, the chief tells the field kitchen boss to cook steamed rice with fried carp for me-Ahh!

-my first decent meal in three years. ${ }^{7}$ 
The executioner, cord coiled

round his shoulder, stares while we eat

in silence. Then Mi Kwohl appears! ${ }^{8}$

Everyone falls over laughing!

"Ta Gold is lucky! Ta almost

travelled to the white bones village!"

I feign not knowing what they mean

and keep stuffing myself with rice.

\footnotetext{
${ }^{1}$ Mi Khowl: Khmer, meaning "cow with short horns"-the female of my team.

${ }^{2} A$ Mahp: Khmer, meaning "fat guy"-the male of my team.

${ }^{3}$ Proloeung: Khmer, meaning "my soul"; this was, at that time, my name for my son. Every time we moved to a different camp I would give him a different name-this was part of our "cover."

${ }^{4}$ them: my son pointed to his invisible companions, the elves, with whom he had been playing and who had consequently rendered him invisible to me, even though, in reality, he had been right there in front of me earlier in the afternoon.

${ }^{5}$ Old People: the Pol Pot clique, and their sympathizers.

${ }^{6}$ evidence: first, I had lost a water buffalo entrusted to me, then she had eaten a large area of rice shoots.

${ }^{7}$ feast: this was a kind of "last supper" provided for people before they were executed. ${ }^{8} \mathrm{Mi}$ Kwohl appears: she, too had been hidden by the elves. I suspect that she had been nearby all that time, but was being ridden about by an elf, therefore invisible.
}

\section{The Moaning Nature of Cambodia}

$$
\text { for Carolyn Forché }
$$

The sugar palms moan; the banyan trees wail; forests, mountains cry for an ideal leader; the Great Lake trembles, fearing oil prospectors; for the generation of roosters is back.

Neem trees are scared of rural development, science, progress; wildlife will vanish for sure. Sewage fouls the environment-no way out. Oh, Cambodia, my beloved motherland! 